\title{
Phenotype-genotype correlation in 20 deletion and 20 non-deletion Angelman syndrome patients
}

\author{
A nne $M$ oncla ${ }^{1}$, Perrine $M$ alzac ${ }^{1}, M$ arie-A ntoinette Voelckel ${ }^{1}$, Pascal A uquier ${ }^{2}$, \\ Lydie $G$ irardot $^{1}$, M arie-G enevieve $M$ attei $^{3}, \mathrm{~N}_{\text {icole }}$ Phili ${ }^{1}{ }^{1}$, J ean-François $M$ attei $^{1}$, \\ $M$ arc $L$ alande ${ }^{4}$ and $M$ arie-O dile Livet ${ }^{5}$ \\ ${ }^{1} D$ épartement de $G$ énétique $M$ édicale, $H$ ôpital des $E$ nfants de la Timone, $M$ arseille \\ ${ }^{2}$ Service de Santé $P$ ublique, Faculté de $M$ édecine, $M$ arseille \\ ${ }^{3} U$ nité IN SE RM 491, Faculté de M édecine, M arseille, France \\ ${ }^{4} \mathrm{G}$ enetics Division, Children's H ospital, $\mathrm{H}$ arvard M edical School and $\mathrm{H}$ oward $\mathrm{H}$ ughes M edical Institute, Boston, \\ USA \\ ${ }^{5}$ Service de Pédiatrie, H ôpital G énéral; A ix en Provence, and Service de Neuropédiatrie, H ôpital des E nfants de la \\ Timone, $M$ arseille, France
}

\begin{abstract}
A ngelman syndrome (AS) is a neurodevelopmental disorder caused by the absence of a maternal contribution to chromosome 15q11-q13. There are four classes of A S according to molecular or cytogenetic status: maternal microdeletion of $15 q 11$ - q13 (approximately $70 \%$ of A S patients); uniparental disomy (UPD); defects in a putative imprinting centre (IM); the fourth includes 20-30\% of A S individuals with biparental inheritance and a normal pattern of allelic methylation in 15q11-q13. Mutations of UBE $3 A$ have recently been identified as causing $A S$ in the latter group. Few studies have investigated the phenotypic differences between these classes. We compared 20 non-deletion to 20 age-matched deletion patients and found significant phenotypic differences between the two groups. The more severe phenotype in the deletion group may suggest a contiguous gene syndrome.
\end{abstract}

Keywords: Angelman syndrome; deletion 15q11-q13; uniparental disomy; imprinting mutation; U B E 3A mutation; G A B R B 3 gene

\section{Introduction}

A ngelman syndrome (AS) is a severe neurodevelopmental disorder with a heterogeneous genetic aetiology. A fter its initial description in $1965^{1}$ the clinical A S phenotype has been well characterised. ${ }^{2}$

Correspondence: A nne M oncla M D, D épartement de G énétique Médicale, Hôpital des Enfants de la Timone, 264, rue Saint Pierre, 13385 Marseille cedex 05, France. Tel: +3304913869 10; Fax: + 3304914941 94; E-mail: amoncla@ap.hm-fr

R eceived 20 February 1998; revised 3 July 1998; accepted 7 A ugust 1998
Common manifestations include severely delayed motor development, mental retardation, speech impairment, gait ataxia, epilepsy with abnormal EE G, as well as physical anomalies such as microcephaly, characteristic facial phenotype, hypopigmentation and scoliosis.

A S results from the lack of contribution of normally active maternally-inherited genes on chromosome 15q11-q13. Interstitial deletions of chromosome 15(q11-q13) account for $70 \%$ of cases (class I). In the $30 \%$ of cases showing no deletion, about 3-5\% result from paternal uniparental disomy (U PD) (class II), and about $5 \%$ are due to imprinting mutations (class III). In 
the remaining $20 \%$ of patients, including numerous familial cases, no molecular abnormality was detectable until the recent finding of $U B E 3 A$ mutations (class IV). . $^{3,4}$

The variability of A S phenotype has been described in few reports, but most of these ante-date the recognition of UPD, imprinting mutations, and abnormalities of UBE3A gene. ${ }^{5-8}$ Phenotypic comparison between deletion and non-deletion AS patients has been reported in only two studies. ${ }^{9,10}$ There were no significant differences except for hypopigmentation, found only in deletion cases. A milder phenotype in paternal UPD cases has been suggested by different authors. ${ }^{11-14}$ On the other hand, Prasad et $\mathrm{al}^{15}$ reported one UPD case without a 'substantially different phenotype from the average severity in deletion case'. Two recent reports of nine and five imprinting mutation cases respectively ${ }^{16,17}$ described no significant differences in the phenotypic spectrum of AS except for more frequent occurrence of microcephaly and hypopigmentation in deletion cases.

In 89 A S patients diagnosed in our Department of $M$ edical Genetics, we found basically the same frequency of main AS manifestations as reported in the literature. ${ }^{2,18} \mathrm{~A}$ part from the pigmentary abnormalities associated with deletion cases, ${ }^{9}$ non-deletion patients nevertheless seemed to have a milder phenotype than deletion ones. To confirm this putative genotypephenotype correlation, we compared the clinical manifestations of a group of 20 non-deletion A S patients consisting of UPD, imprinting mutations, and UBE $3 A$ mutations to those of an age-matched control group of 20 deletion cases.

\section{Subjects and Methods}

The 40 patients were part of a survey of 89 A S patients diagnosed between 1989 and 1996, and evaluated by the same clinical geneticist and neuropaediatrician. Since the phenotypic expression of AS is age-dependent, ${ }^{8}$ each non-deletion patient was compared to an agematched patient with a deletion. The $20 \mathrm{~A} S$ patients of both groups were further divided into three categories: ten children (4-13 years), three adolescents (15-17 years), and seven adults (18-36 years). The following physical and neurological parameters were systematically evaluated: height, weight and head circumference, ability to walk and age of onset, epilepsy with age of onset and type of seizures, tremulous movements, language performance, communication abilities.
Microcephaly was defined as a head circumference smaller than the mean value by at least two standard deviations. ${ }^{19}$ Skin, hair, and iris pigmentation was evaluated by comparison with that of the parents and normal sibs.

A combination of molecular and cytogenetic analyses was used to classify patients according to molecular groups as previously defined. ${ }^{20}$ Procedures for DNA extraction, DNA methylation test with probes PW 71B (D 15S63) and SNRPN 5'-end, microsatellite studies, cytogenetic analysis, and FISH followed standard protocols. ${ }^{3,21-31}$ In patients with biparental inheritance of chromosome 15 and normal methylation status, recent molecular screening for UBE $3 A$ mutations was initiated by SSCP analysis; it will be described elsewhere ( $M$ alzac et $\mathrm{al}^{32}$ ). The two groups of A S patients are as follows:

The deletion group included seven females and 13 males. A II cases were sporadic. In two individuals, the deletion arose as the result of an unbalanced de novo translocation: $45, X Y, \operatorname{der}(1) \mathrm{t}(1 ; 15)$ (qter-q13),-15 and $45, X Y, \operatorname{der}(15) t(15 ; 22)$ (q12-p11), -22. Three of the patients including those with unbalanced translocation have been previously reported..$^{33,34}$ The origin of the deleted chromosome was maternal in probands. $\mathrm{N}$ ot all patients were tested or were informative for each probe, but there was sufficient information to establish that the deletion spanned the entire region commonly deleted in $\mathrm{A} \mathrm{S.}^{35}$

The non-deletion group included five females and 15 males. There were nine sporadic cases and 11 familial cases from five unrelated families: two sets of siblings (two females with consanguineous parents and one family with a male and a female sibling), and three larger families (two brothers and one female first cousin; one male, two first cousins and a maternal uncle, and one family with seven affected cases in three generations). In the latter two families, two cases are currently being evaluated. The molecular findings in this group are as follows:

1 Three sporadic patients with paternal U PD (class II).

2 Three sporadic cases with an abnormal methylation pattern with PW 71B and/or SNRPN and biparental inheritance of chromosome 15 (class III).

3 Three sporadic cases and all the familial cases had biparental inheritance of chromosome 15 and normal methylation. Recent screening for 
U BE $3 A$ mutations detected three frameshift mutations in the sporadic cases (exon 8, exon 10, exon 15), five mutations in the familial cases with four frameshift mutations (exon 9, exon 10, exon 12, exon 16), and one amino-acid insertion mutation (exon 15) (class IV).

For both groups of patients, the frequency (quantitative parameter) and age of onset (qualitative parameter) of the symptoms were studied. To assess whether differences in distribution of the frequencies of a particular manifestation were significant, we used Fisher's exact test. If the data concerning a clinical parameter was unknown, the patient and the agematched patient were excluded from the calculation (values given Table 1). The null hypothesis that the frequencies of respective symptoms in deletion and non-deletion patients are different was rejected at the $5 \%$ level $(P>0.05)$. Qualitative parameters were studied by analysis of variance (A NOVA). Because both groups were small, significance was confirmed by the Mann-W hitney parametric test.

\section{Results}

The distribution of each of the major manifestations of A S for the two groups is presented in Table 1.

\section{Microcephaly}

In deletion patients, a microcephaly was present by 2 years in 18 of 20 patients (90\%) (Figure 1 ).

In non-deletion patients, a microcephaly was present in seven of 20 cases (35\%) (Figure 1). No patients from either group had a head circumference above the mean value.

The $P$ value is significant for microcephaly $(P<0.001)$.

\section{Ability to Walk and Age at Onset}

In the deletion patients, 15 of 20 patients (75\%) could walk independently at the last review. Mean age of walking was 5.2 years and varied between 2.5 to 10 years (Figure 2 ). Of the five patients $(25 \%)$ who could not walk independently, two were aged 5 , and the others were 6, 22 and 23 years old. In the adult group two patients showed loss of ambulation and became wheelchair-bound.

A II non-deletion patients could walk independently. The age at which walking began varied between 19 months and five years of age; mean value was 30 months (Figure 2). None presented with walking difficulties as they grew older.

The $P$ value for ability and age of walking between the two groups was significant, 0.047 and 0.001 respectively.

\section{Epilepsy}

A II patients with a deletion had epilepsy which started before 3 years of age in 18/20 cases. A ge of onset varied between 6 months and 5 years (Figure 3), with a mean at 20 months. The main ictal patterns were atypical absence seizures, myoclonic-atonic seizures, and tonicclonic seizures. Infantile spasms were observed in two cases. M yoclonic status with decreased alertness and loss of smile, lasting several days or weeks, was reported in four patients. In all cases, EEG showed the

Table 1 Distribution of each major manifestation between deletion and non deletion cases

\begin{tabular}{|c|c|c|c|c|c|c|c|}
\hline \multirow{2}{*}{$\begin{array}{l}\text { G roups of patients } \\
\text { Clinical evaluation }\end{array}$} & \multicolumn{3}{|l|}{ Deletion } & \multicolumn{3}{|c|}{ Non deletion } & \multirow[b]{2}{*}{$P$ value } \\
\hline & M ean age & number & $\%$ & M ean age & number & $\%$ & \\
\hline A ge at diagnosis (years) & 11.4 & & & 12.8 & & & NS \\
\hline before 3 years & & $8 / 20$ & 40 & & $4 / 20$ & 20 & \\
\hline 4 to $<18$ years & & $6 / 20$ & 30 & & $9 / 20$ & 45 & \\
\hline$\geq 18$ years & & $6 / 20$ & 30 & & $7 / 20$ & 35 & \\
\hline M icrocephaly & & $18 / 20$ & 90 & & $7 / 20$ & 35 & $<0.001$ \\
\hline D elay in growth $\mathrm{HC}$ & & $19 / 20$ & 95 & & $15 / 20$ & 75 & NS \\
\hline A bility to walk & & $15 / 20$ & 75 & & $20 / 20$ & 100 & 0.047 \\
\hline A ge of onset (years) & 5.2 & & & 2.6 & & & $<0.001$ \\
\hline Seizures & & $20 / 20$ & 100 & & $14 / 20$ & 70 & 0.02 \\
\hline A ge of onset (years) & 1.8 & & & 5.4 & & & 0.004 \\
\hline Cortical myoclonus & & $17 / 19$ & & & $18 / 20$ & & NS \\
\hline G rowth retardation ( $\leq-2 \mathrm{SD}$ ) & & $10 / 20$ & 50 & & 2 & 10 & 0.013 \\
\hline A dult group & & $5 / 7$ & 71.5 & & $2 / 7$ & 28.6 & \\
\hline O besity $(\geq+2 S D)$ & & $3 / 20$ & 15 & & $10 / 20$ & 50 & 0.013 \\
\hline O verweight ( $\geq$ + 1SD) & & $9 / 20$ & 45 & & $15 / 20$ & 75 & NS \\
\hline H ypopigmentation & & $15 / 20$ & 75 & & $0 / 20$ & 0 & $<0.001$ \\
\hline
\end{tabular}


typical pattern for A S: $:^{35,36}$ high voltage, atypical slow spike waves with a maximum over the frontal or occipital regions and sometimes diffuse. A II patients were treated with valproic acid and/or benzodiazepines. In the child group, seizures continued but with very low

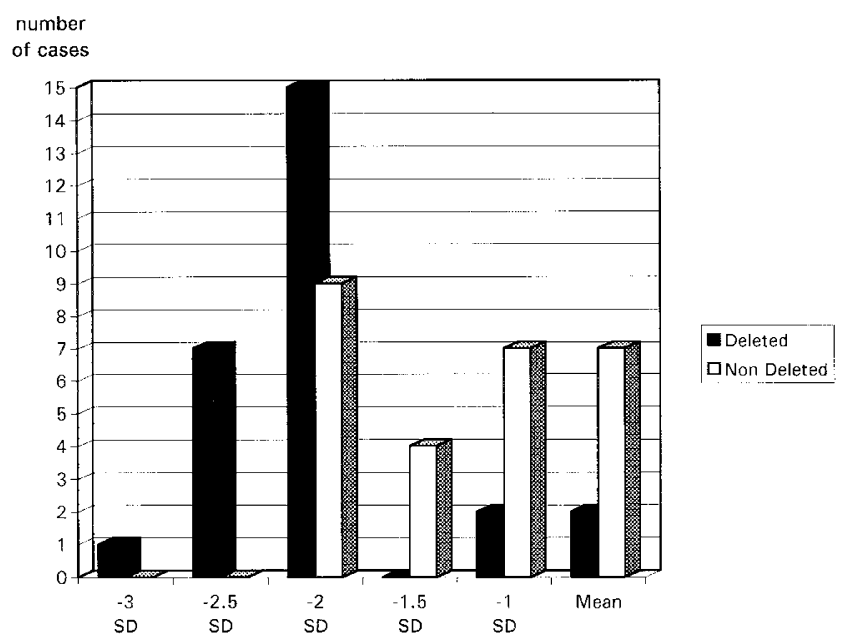

Figure 1 Distribution of head circumference $(\mathrm{HC})$ between 20 AS patients with deletion and 20 AS patients without deletion. activity in seven cases; three of them became seizurefree 2-3 years after treatment initiation. The three remaining child cases were more severe. In the adolescent and adult group, epilepsy never improved in four cases, and the frequency and duration of epileptic seizures became worse in adult age. In four cases, there was recurrence during adulthood. In only two adult cases did epilepsy and EE G pattern show improvement with age.

Tremor, recently related to fast-bursting cortical myoclonus, occurred periodically in the majority of the deletion patients (17/19 cases). ${ }^{37}$ We observed that this phenomenon appeared more pronounced in adolescents and adults, increasing when triggered by stress or strain, and that it could lead to typical myoclonic seizures and/or myoclonus status.

In non-deletion cases, epilepsy was present in 14 of 20 cases (70\%). A ge at onset ranged from 6 months to 20 years with a mean age at 5.4 years (Figure 3 ). The most frequent ictal patterns were atypical absences and myoclonic seizures. In three cases (one adolescent and two adults), generalised clonic seizures were observed. Seizures remained rare in all patients and cessation of treatment was possible in some cases. The seven

Number of

cases

Non Deleted

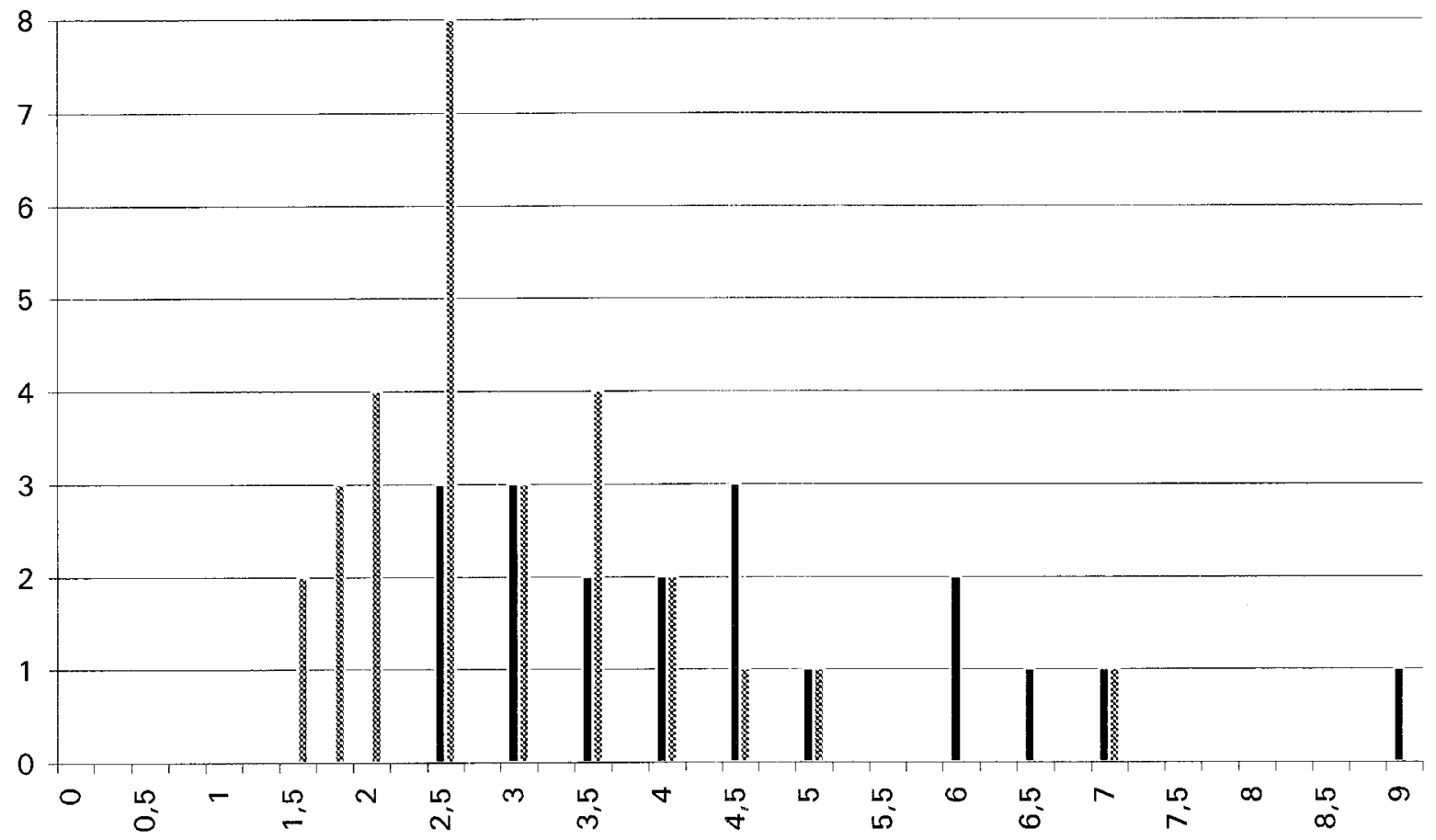

Figure 2 Distribution of age of onset of walking between 15 AS patients with deletion and 20 AS patients without deletion (5 AS deleted patients did not walk at the last review). 
seizure-free patients were aged from 4 to 30 years. However, EEG patterns were abnormal in all cases whatever their age.

Tremor also occurred in the majority (18/20), either with or without seizures but was often more pronounced with increasing age. It was correlated with onset or recurrence of typical myoclonus seizures and/ or myoclonus status in adolescents or adulthood (three cases).

$P$ value of frequency of epilepsy and age of onset between the two groups was significant ( 0.02 and 0.004 , respectively).

\section{Language and Communication}

N one of the deleted patients had developed any speech, except 'papa, mama', or rare speech-like syllables. Severe oral motor dyspraxia was a consistent finding. Patients never acquired any ability to execute familiar oral acts, like kissing, on command. Performing a single order was usually possible, if the child was well motivated. Imitation skills remained poor. Patients were not able to imitate expressive motor patterns except for occasional waving or clapping. In non-verbal communication, most children had the ability to express their basic needs and food preferences. They usually used repeated touching to get attention and guided adults by the hand to what they wanted, but neither pointing nor communication through gestures was established. The vast majority of teenagers and adults were totally dependent in daily life, requiring assistance with feeding, toilet, and dressing.

Most of the non-deletion patients were able to acquire a few words (usually four to ten words). Four subjects could say 20 'words' or more. In fact, patients only utter one or two syllables of each word, with very defective articulation. Oral praxies were deficient, but kissing became possible for most of them. Patients were able to designate parts of the body or pictures (animals), to execute complex orders, and to imitate motor patterns and some simple gestures. Their nonverbal communication was particularly efficient, with ability to use pointing and, above all, to elaborate a private gestural code quite clear to other family members. The vast majority of teenagers and adults were able to dress and feed themselves without assistance.

\section{Height and Weight}

In deletion patients, height was retarded by -2SD in 10 of 20 cases $(50 \%)$. In the adult cases, there was a definitive small height in five of seven cases (Figure 4). Excessive weight ( $\geq 1 S D$ relative to height) was present in $9 / 20$ cases (45\%) (4/10 children, 2/3 adolescents, and $3 / 7$ adults). O besity ( $\geq 2$ SD above normal value) was present in three of 20 cases (15\%) (in one child, one adolescent, and one adult).

In non-deletion patients, growth was retarded by -2 SD in only two adults (10\%) (Figure 4). G rowth rate was within normal value in all the remaining cases ( 12 cases at mean value, five at $+1 S D)$. A bove average weight was present in $15 / 20$ cases (75\%) ( $7 / 10$ children, $2 / 3$ adolescents, and $6 / 7$ adults). 0 besity was present in 10/20 (five children, one adolescent, and four adults). The $P$ values for growth retardation and obesity between the two groups were significant at 0.013 and 0.013 , respectively, whilst that for overweight was not.

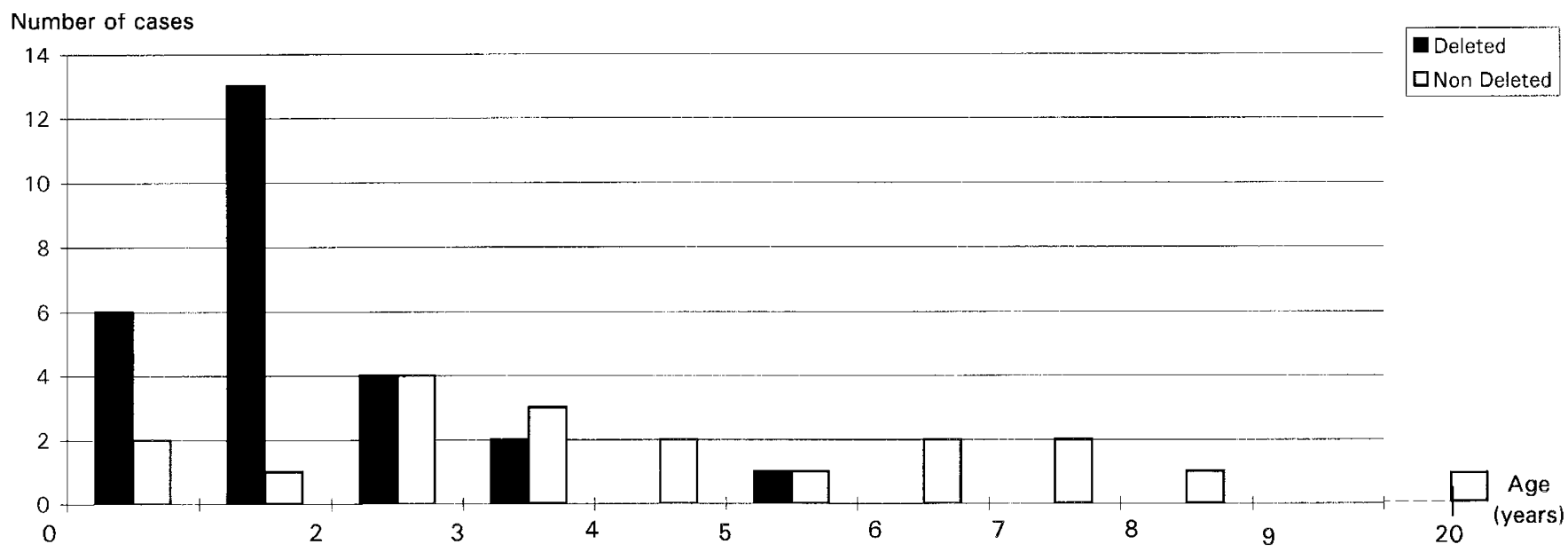

Figure 3 D istribution of age of onset of seizures between 20 AS patients with deletion and 20 AS patients without deletion (six AS non-deletion patients did not present seizures at the last review.) 
UPD ${ }^{14}$ or imprinting mutations ${ }^{16,17}$ with those with

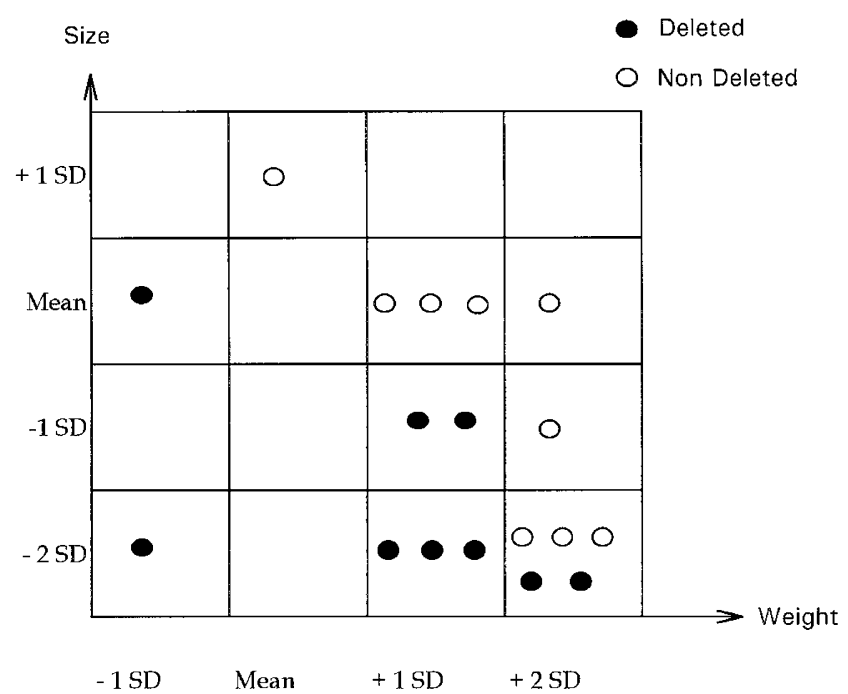

Figure 4 Distribution of height and weight between seven AS adults patients with deletion and seven AS adults patients without deletion.

\section{Pigmentation}

In deletion patients, hypopigmentation was a feature in $15 / 20$ cases ( $75 \%$ ). In one adult, it was present during childhood but was less evident with age. In one child of I talian origin, pigmentation appeared to be normal. The other three patients were adults and no data was available for early age. A mong non-deletion patients, none was hypopigmented. The $P$ value for hypopigmentation between the two groups was significant $(P<0.001)$.

\section{Discussion}

We have compared the clinical phenotype of 20 molecularly well defined non-deletion A S patients with that of 20 deletion patients. To the best of our knowledge, this is the first age-matched comparative clinical study in A S to include in addition the study of both qualitative and quantitative parameters for each major clinical manifestation of the syndrome.

Table 1 summarises the comparison between the two groups. O ur results statistically demonstrate that a less severe phenotype is associated with non-deletion A S with respect to both physical anomalies and neurological manifestations.

Deletion and non-deletion AS patients have been compared in only two reports, ${ }^{9,10}$ but in these papers the non-deletion groups are not molecularly well defined. More recent studies compared molecularly well defined small groups of A S patients - those with classical deletion. In all these reports, only the frequency of each major manifestation of A S was evaluated. Clinical details have been reported in two large surveys of deletion patients ( 37 from Japan ${ }^{9}$ and 27 from Australia ${ }^{39}$ ). To date, a total number of 39 molecularly well characterised non-deletion patients have been clinically described including 16 U PD ${ }^{11-15,40}$ 14 imprinting mutations, ${ }^{16,17}$ and nine with UBE $3 A$ mutations. ${ }^{4-43}$ We excluded reports of familial A S with incomplete molecular analysis.

The present study demonstrates a clear difference in the degree of microcephaly between the two groups ( $90 \%$ in deletion and $35 \%$ in non-deletion). In the deletion group, microcephaly is more frequent than in previous reports, ${ }^{9,39}$ although an exact comparison is difficult to make due to differences in patient ages and measurement parameters used. In the total number of 39 non-deletion patients, microcephaly is observed in 16 cases $(41 \%))^{11-17,40,41,43}$

In addition, facial dysmorphism appeared milder in $13 / 20$ non-deletion cases in comparison with the typical facial appearance observed in 19/20 of the deletion patients. This difference was more obvious in the adult group (Figure 5) but should be confirmed by objective facial measurements.

A significant difference in body height was observed between the two groups. Growth retardation was associated only with deletion and UBE $3 A$ mutations. A Il patients with imprinting mutations or UPD were within the mean range for height. A significant difference was also noted in the frequency of obesity between the two groups. Increase in weight often began in late childhood, and was correlated with hyperphagia. Parents described a behavioural phenotype (food seeking and stealing) similar to the one associated with Prader-Willi syndrome (PWS). This observation points to an overlap between AS and PWS as previously reported in two A S patients. ${ }^{44}$ Recently, Cattanach et $\mathrm{al}^{45}$ described an A S mouse model with partial paternal disomy for the syntenic region. I nterestingly, this mouse model exhibits obesity. Few data are available on growth parameters in $\mathrm{AS}^{18,39,46}$ and further clinical studies on large A S series are needed to confirm these results.

Study of neurodevelopmental parameters in both patient groups demonstrated a less severe phenotype in the non-deletion group. A bility to walk independently and age at onset were significantly different between the two groups. Two studies also reported earlier onset 
of walking in non-deletion patients. ${ }^{17,14} \mathrm{~A}$ ge of onset and ability to walk appear dependent on the degree of expression of two parameters: ataxia and seizures. Moderate to very mild ataxia is consistently found in the non-deletion group as well as a less severe epilepsy phenotype. Concerning epilepsy, we have seen distinctive patterns between the two groups. In the deletion
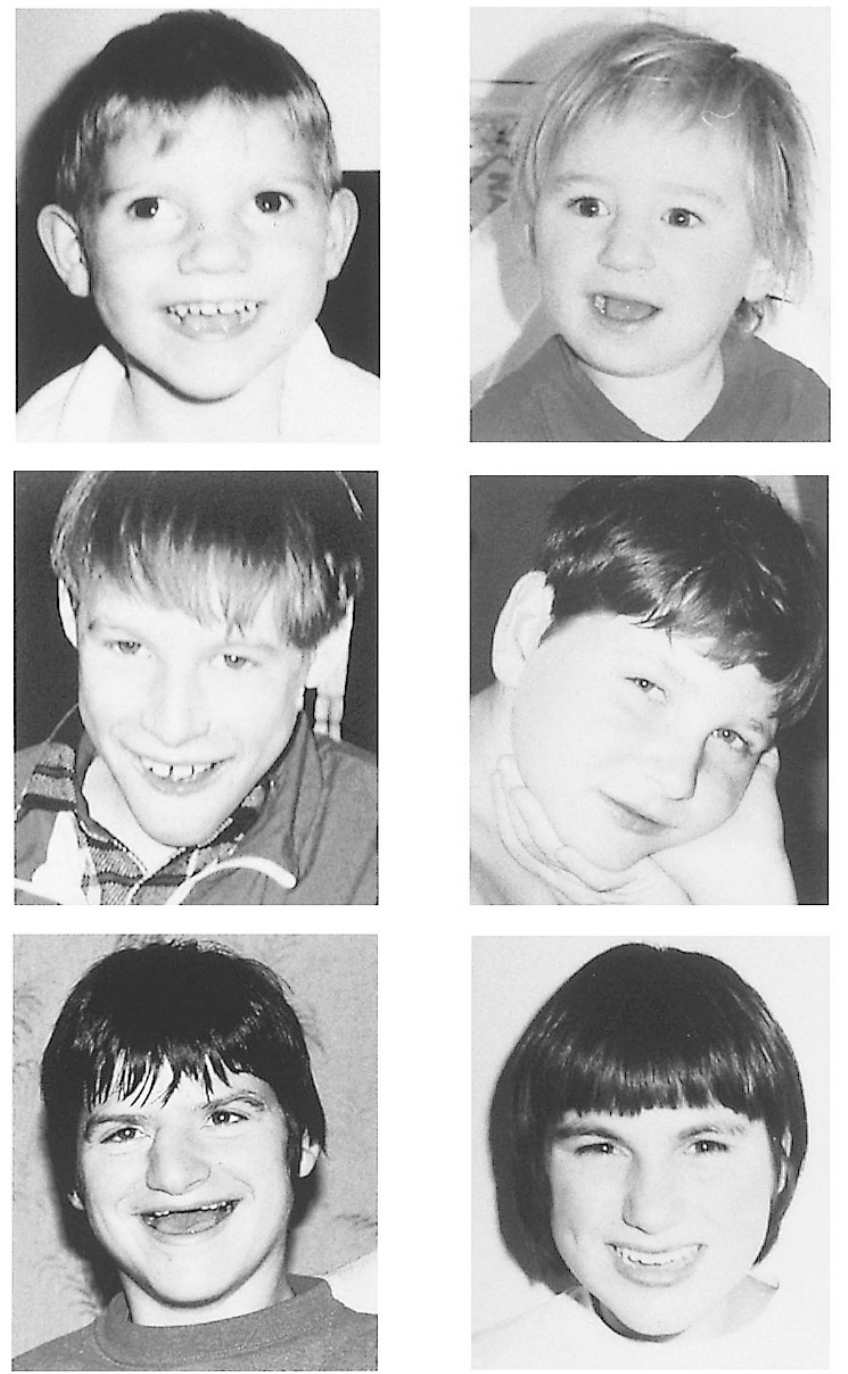

Figure 5 Comparison of facial dysmorphism between patient with del etion and patient without del etion (left: del etion patient; right: non-deletion patient). cases, epilepsy always began early, prior to 3 years of age. It was often severe, especially during childhood. Even when seizures were less frequent, treatment needed to be maintained. In non-deletion cases, epilepsy was not a consistent manifestation and was less severe. The age of onset varied greatly from infancy to adulthood. The frequency of epilepsy previously reported for deletion patients was $100 \%$ and $96 \%,{ }^{9,38}$ In non-deletion patients, epilepsy is less frequent; it was reported in 19/38 cases (50\%). ${ }^{11-17,40,41,43}$

Severe mental retardation and a marked lack of expressive speech are obvious and permanent features of AS in late infancy. However, clinical evaluation enabled us to find significant variations in the level of cognitive abilities and communication skills. Such differences had been noticed previously in a study of 11 A S cases with only the familial patients able to imitate and learn a few words. ${ }^{47}$

In addition, we observed a different distribution of both physical and neurological parameters between the three molecular classes of the non-deletion group (Table 2). M icrocephaly is less frequent both in imprinting mutations $(3 / 17 ; 17.7 \%)$ and UPD $(6 / 19 ; 31.6 \%)$ compared with UBE3A mutations (14/22; 63.6\%). Similarly, epilepsy was less frequent both in U PD (8/17; $47.1 \%)$ and imprinting mutations (11/17; $64.7 \%$ ) compared with UBE3A mutations (17/23; 74\%). Our patients with UBE3A mutations presented a more significant variability both in age of onset and frequency of crisis compared to those with UPD and imprinting mutations, and only some patients with U BE 3A mutation showed growth retardation.

This study raises the question of whether mutation or deletion of only the imprinted UBE3A gene can explain the more frequent microcephaly and the severe epilepsy phenotype found in patients with common large deletion. The deleted region includes a cluster of $G A B A_{A}$ receptor subunit genes (GABRB 3, GABRA 5, and $G A B R G 3$ ). These genes are involved in inhibiting synaptic transmission and are highly expressed in embryonic brain. ${ }^{48}$ I nitially, G A BRB 3 was proposed as an AS candidate gene, ${ }^{49}$ but it was then excluded because a subtle microdeletion not encompassing the

Table 2 Frequency of epilepsy and microcephaly among the three molecular classes of our non-deletion group and previous reports

\begin{tabular}{|c|c|c|c|c|c|c|c|c|c|}
\hline & \multicolumn{3}{|l|}{ UPD } & \multicolumn{3}{|c|}{ Imprinting mutation } & \multicolumn{3}{|c|}{ UBE3A mutation } \\
\hline & P resent study & O ther* & Total \% & Present study & O ther ${ }^{a}$ & Total \% & P resent study & O ther* & Total \% \\
\hline M icrocephaly & $1 / 3$ & $5 / 16$ & 31.6 & $0 / 3$ & $3 / 14$ & 17.7 & $6 / 14$ & $8 / 8$ & 63.6 \\
\hline E pilepsy & $2 / 3$ & $6 / 14$ & 47 & $2 / 3$ & $9 / 14$ & 64.7 & $9 / 14$ & $8 / 9$ & 74 \\
\hline
\end{tabular}

references 11-17, 40, 41, 43. 
gene cluster was found in one A S patient $\mathrm{t}^{50}$ and because of its biallelic expression in mouse brain. ${ }^{51}$ Recently, targeted disruption of GABRB 3 has been performed and homozygous mutant mice exhibit epilepsy, EEG abnormalities, and a phenotypic behaviour similar to $A_{S}{ }^{52}$ Hence, the role of these genes in the AS phenotype cannot be definitively excluded but remains unclear.

In conclusion, deletion A S cases correspond well to the initial clinical description of A ngelman. ${ }^{1}$ Cases without deletion appear to have a milder expression of the main neurological manifestations and physical anomalies. These findings are particularly important for clinical diagnosis, because a milder phenotype can be associated with molecular classes having a potential high risk for recurrence. A clinical severity scale from more to less severe can be summarised as follows: deletion cases > UBE $3 \mathrm{~A}$ mutation cases > imprinting mutation and/or UPD cases. This type of phenotypegenotype correlation study represents a first step towards further understanding of both the molecular basis of AS and the role of imprinting in this syndrome.

\section{Acknowledgements}

We are grateful to all families, the A ssociation Française du Syndrome d'A ngelman (A FSA) and all the clinicians who referred patients for their cooperation in this study. We thank D r J Wagstaff for help in screening for UBE $3 A$ gene in our patients. We particularly thank D r S A ymé for critical reading of the manuscript.

\section{References}

1 A ngelman $\mathrm{H}$ : 'Puppet children': a report of three cases. Dev Med Child Neurol 1965; 7: 681-688.

2 Williams CA, A ngelman $\mathrm{H}$, Clayton-Smith J et al: A ngelman syndrome: Consensus for diagnosis criteria. A m J Med G enet 1995; 56: 237-238.

$3 \mathrm{~K}$ ishino T, L alande M, Wagstaff J : U BE 3A /E 6-A P mutations cause A ngelman syndrome. Nat $\mathrm{G}$ enet 1997; 15: 70-73.

$4 \mathrm{M}$ atsuura T, Sutcliffe J S, Fang $P$ et al: De novo truncating mutations in E6-AP ubiquitin-protein ligase gene (UBE 3A ) in A ngelman syndrome. $\mathrm{N}$ at $\mathrm{G}$ enet 1997; 15: 74- 77.

5 R obb SA, Pohl KRE, Baraitser M, Wilson J, Brett EM : The 'happy puppet' syndrome of A ngelman: review of the clinical features. A rch D is Child 1989; 64: 83-86.

6 Zori RT, Hendrickson J, Woolven S, Whidden EM, Gray $B$, Williams CA : A ngelman syndrome: Clinical profile. J Child Neurol 1992; 7: 270-280.
7 Clayton-Smith J: Clinical research on A ngelman syndrome in the $U$ nited Kingdom: observations on 82 affected individuals. A m J M ed G enet 1993; 46: 12-15.

8 Buntinx IM , H ennekam R CM , B rouwer OF et al: Clinical profile of $A$ ngelman syndrome at different ages. A m J M ed G enet 1995; 56: 176-183.

9 Saitoh S, Harada N, J inno $Y$ et al: M olecular and clinical study of $61 \mathrm{~A}$ ngelman syndrome patients. A m J M ed G enet 1994; 52: 158-163.

$10 \mathrm{Hou}$ JW, Wang PJ, Wang TR: A ngelman syndrome assessed by neurological and molecular cytogenetic investigations. Pediatr Neurol 1997; 16(1): 17-22.

11 Freemam SB, M ay KM, Pettay D, Fernhoff PM, H assold TJ: Paternal uniparental isodisomy in a child with a balanced 15;15 translocation and A ngelman syndrome. A m J M ed G enet 1993; 45: 625-630.

12 Bottani A, Robinson WP, Delozier-Blanchet CD et al: A ngelman syndrome due to paternal uniparental disomy of chromosome 15: A milder phenotype?. Am J Med G enet 1994; 51: 35-40.

13 Gillessen-K aesbach G, A lbrecht B, Passarge E, Horsthemcke $B$ : F urther patient with $A$ ngelman syndrome due to paternal disomy of chromosome 15 and a milder phenotype. A m J M ed G enet 1995; 56: 328-329.

14 Smith A, Marks R, Haan E, Dixon J, Trent RJ : Clinical features in four patients with A ngelman syndrome resulting from paternal uniparental disomy. J M ed G enet 1997; 34: 426-429.

15 Prasad C, Wagstaff J: Genotype and phenotype in A ngelman syndrome caused by paternal UPD 15. Am J M ed G enet 1997; 70: 328-329.

16 Bürger J, Kunze J, Sperling K, R eis A: Phenotypic differences in A ngelman syndrome patients: Imprinting mutations show less frequently microcephaly and hypopigmentation than deletions. A m J M ed G enet 1996; 66: 221-226.

17 Saitoh S, Buiting K, Cassidy SB, Conroy J M et al: C linical spectrum and molecular diagnosis of $A$ ngelman and Prader-Willi syndrome patients with imprinting mutation. A m J M ed G enet 1997; 68: 195-206.

18 Clayton-Smith J, Pembrey ME: A ngelman syndrome. J Med G enet 1992; 29: 412-415.

19 G orlin RJ, Cohen M M, Levin LS: Syndromes of the $\mathrm{H}$ ead and Neck, 3rd edn. Oxford U niversity Press, New York 1990.

20 A merican Society of Human Genetics/A merican College of Medical G enetics Test and Technology Transfer Committee: Diagnostic testing for Prader-Willi and A ngelman syndromes. A m J H um G enet 1996; 58: 1085-1088.

21 Chan C-TJ, Clayton-Smith J, Cheng X-J et al: Molecular mechanisms in A ngelman syndrome: a survey of 93 patients. J M ed G enet 1993; 30: 895-902.

22 Sutcliffe J S, Nakao M, Christian S et al: Deletions of a differentially methylated CPG island at the SNRPN gene define a putative imprinting control region. Nat Genet 1994; 8: 52-58.

23 Y unis J]: H igh resolution of human chromosomes. Science 1976; 191: 1268-1270.

24 Nicholls R D, K noll J H, G latt $\mathrm{K}$ et al: R estriction fragment length polymorphisms within proximal $15 q$ and their use in molecular cytogenetics and the Prader-Willi syndrome. A m J M ed G enet 1989; 33: 66- 77. 
$25 \mathrm{Knoll} J H M$, Nicholls RD, Magenis RE, Graham JM, Lalande $M, L$ att $S A$ : A ngelman and Prader-Willi syndromes share a common chromosome 15 deletion but differ in parental origin of the deletion. A m J M ed G enet 1989; 32: 285-290.

$26 \mathrm{~K}$ noll JHM, Nicholls RD, Magenis RE, Graham JM, $K$ aplan L, Lalande $M$ : A ngelman syndrome: three molecular classes identified with chromosome 15q11-q13 specific DNA markers. A m J H um G enet 1990; 47: 149-155.

27 Mutirangura A, Ledbetter SA, Kuwano A, C hinault A C, $L$ edbetter $D H$ : Dinucleotide repeat polymorphism at the $\mathrm{GA} \mathrm{BA}_{\mathrm{A}}$ receptor $\beta 3$ (GABRB3) locus in the A ngelman/ Prader-Willi region (AS/PWS) of chromosome 15. Hum M ol G enet 1992a; 1: 67.

28 M utirangura A, Kuwano A, L edbetter SA, Chinault A C, L edbetter $D H$ : Dinucleotide repeat polymorphism at the D $15 S 11$ locus in the Angelman/Prader-Willi region (A S/PWS) of chromosome 15. H um M ol G enet 1992b; 1 : 139.

29 Mutirangura A, G reeberg F, Butler MG et al: Multiplex PCR of three dinucleotide repeats in the A ngelman/ Prader-Willi critical region (15q11-q13): Molecular diagnosis and mechanism of uniparental disomy. $\mathrm{Hum} \mathrm{Mol}$ G enet 1993; 2: 143-151.

30 Smith A, Prasad M, Deng Z-M, R obson L, Woodage T, Trent $\mathrm{RJ}$ : Comparison of high resolution cytogenetics, fluorescence in situ hybridisation (FISH) and DNA studies to validate the diagnosis of the Prader-Willi and A ngelman syndromes. A rch D is Child 1995; 72: 397-401.

31 Dittrich $B$, Robinson WP, K noblauch $H$ et al: Molecular diagnosis of the Prader-Willi and A ngelman syndromes by detection of parent-of-origin specific DNA methylation in 15q11-q13. H um M ol G enet 1992; 2: 1995-1999.

32 Malzac $P$, Webber $H, M$ oncla $A$ et al: M utation analysis of UBE $3 A$ in A ngelman syndrome patients. Am J Hum G enet 1998; 62, 6: 1353-1360.

33 M attei JF, M attei MG, G iraud F: Prader-Willi syndrome and chromosome 15. A clinical discussion of 20 cases. H um G enet 1983; 64: 356-362.

34 Zori R, Williams CA, M attei J F, M oncla A : Parental origin of del(15)(q11-13) in A ngelman and Prader-Willi syndromes. A m J M ed G enet 1990; 37: 294-295.

35 Christian SL, R obinson W P, H uang B: M olecular characterization of two proximal deletion breakpoint regions in both Prader-Willi and A ngelman syndrome patients. A m J H um G enet 1995; 57: 40-48.

36 Boyd SG, Harden A, Patton MA: The EEG in early diagnosis of the A ngelman (Happy Puppet) syndrome. Eur J Pediatr 1988; 147: 508-513.

37 Viani $F$, Romeo A, Viri $M$ et al: Seizures and EEG patterns in A ngelman's syndrome. J Child N eurol 1995; 10: 467-471.

38 Guerrini R, DeL orey TM, Bonanni $P$ et al : Cortical myoclonus in A ngelman Syndrome. A nn N eurol 1996; 40: $39-48$.
39 Smith A, Wiles C, Haan E et al: Clinical features in 27 patients with A ngelman syndrome resulting from DNA deletion. J M ed G enet 1996; 33: 107-112.

40 Tonk V, Schultz RA, Christian SL, Kubota T, Ledbetter $\mathrm{DH}$, Wilson $\mathrm{GN}$ : R obertsonian $(15 \mathrm{q} ; 15 \mathrm{q})$ translocation in a child with $A$ ngelman syndrome: E vidence of uniparental disomy. A m J M ed G enet 1996; 66: 426-428.

41 Meijers-H eijboer EJ, Sandkuijl LA, Brunner HG et al: Linkage analysis with chromosome 15q11-13 markers shows genomic imprinting in familial A ngelman syndrome. J M ed G enet 1992; 29: 853-857.

42 B eaudet $A L, M$ atsuura T, Fang $P$ : Truncating mutations in E 6-A P ubiquitin-protein ligase (UBE $3 A$ ) cause sporadic and inherited A ngelman syndrome. A ngelman Syndrome Foundation Scientific Symposium (abstract), Seattle, Washington, July 2-3, 1997.

43 G reger V, K noll JHM, Wagstaff J: A ngelman Syndrome associated with an inversion of chromosome 15q11.2q24.3. A m J H um G enet 1997; 60: 574-580.

$44 \mathrm{~K}$ irkilionis A J, Chudley A E, G regory CA , H ammerton J L: Molecular and clinical overlap of A ngelman and PraderWilli syndromes phenotypes. A m J Med Genet 1991; 40: 454-459.

45 Cattanach B M , B arr JA, B eechey CV, M artin J, N oebels J, Jones]: A candidate model for $A$ ngelman syndrome in the mouse. M amm G enom 1997; 8: 472-478.

$46 \mathrm{~L}$ aan $\mathrm{LAEM}$, Den B oer AT, Hennekam RCM, Renier WO, B rouwer O F : A ngelman syndrome in adulthood. A m J Med Genet 1996; 66: 356-360.

47 Jolleff N, Ryan MM: Communication development in A ngelman's syndrome. Arch Dis Child 1993; 69: 148- 150.

48 O Isen RW, A voli M : G aba and epileptogenesis. E pilepsia 1997; 38: 399-407.

49 Wagstaff J, Knoll JHM, Flemming J: Localization of the gene encoding the GABA receptor beta 3 subunit to the A ngelman/Prader-Willi region of human chromosome 15 . A m J H um G enet 1991b; 49: 330-337.

50 R eis $A$, K unze J, L adanyi $L$, E nders $H$, K lein-Vogler $U$ Nieman $G$ : Exclusion of the $\mathrm{GA} \mathrm{BA}_{\mathrm{A}}$ receptor $\beta 3$ sub-unit gene as the A ngelman's syndrome gene. $L$ ancet 1993; 341: 9.

51 Nicholls RD, Gottlieb W, R ussell LB, Davda M, Horstemcke $B, R$ inchik EM : E valuation of potential models for imprinted and nonimprinted components of human chromosome 15q11-q13 syndromes by fine-structure homology mapping in the mouse. Proc N atl A cad Sci USA 1993; 90: 2050-2054.

52 Homanics GE, DeL orey TM, Firestone LL et al: Mice devoid of $\gamma$-aminobutyrate type $A$ receptor $\beta 3$ subunit have epilepsy, cleft palate, and hyperactive behavior. P roc Natl A cad Sci USA 1997; 94: 4143-4148. 